\title{
The Analysis of the Development of Futures Investment Funds in China
}

\author{
Zhe Jing Zhang ${ }^{1}$ \\ ${ }^{1}$ A teacher with a lectureship in Langfang Polytechnic Institute, Hebei Province, China
}

Abstract. This paper introduces the futures investment fund, elaborates on its functions and puts forward its problems in China. It also comes up with some personal suggestions for reference based on the measures for its development.

\section{An overview of futures investment funds}

In the 1940's, futures investment funds appeared in the United States market. As time goes by, they have greatly developed in the United States and has a stable scale. With the continuous progress made in the world financial market, the development of the futures investment fund has reached a higher level in the United States. In recent years, with the development of social economy in China, Chinese economy continues to improve and the financial market has been fully developed, which provides opportunities for the development of the futures investment funds in China that has become an inevitable trend in China's financial market.

The so-called futures investment fund, from a broad sense, is "the management of futures". It means that investors make use of financial management provided by professional fund managers, the global futures market and option market for investment. Investors can carry out physical commodities trading in the investment market. They can also carry out futures or option contract trading; from a limited sense, futures investment fund is also known as "mutual futures fund". It is a kind of innovation of the investment fund and is mainly used in futures investment. Its operating process is similar to the public fund.

\section{Functions of futures investment funds}

\subsection{To control transaction exposure and ensure the return on investment}

Compared with traditional investment portfolios, the advantages of adding futures investment funds into the investment portfolio are very prominent, which can effectively control price fluctuations in the traditional investment portfolio, investment risk can be reduced, and increase the return on investment.

\subsection{To use short-selling mechanism to resist the economic downturn}

Investors face a variety of investment risks in the futures investment market which can be summarized as "high risks, high profits". Due to the high risk in the futures investment market, they have to choose a reasonable investment portfolio in order to effectively avoid the investment risk and guarantee the profitability of investment. Investment risks brought by futures investment funds can be effectively avoided in the futures market by reasonable investment portfolio strategies which can increase investment income. Compared to stock investment and bond investment, futures investment funds are much more flexible and unstable. If the economic cycle is in a recession or on the edge of a recession, it will cause the stock price to fall and economic collapse. But futures investment funds can remain profitable in this case. The reasons are due to the flexible operation of futures investment funds. Investment is controlled by the price fluctuations to guarantee that it makes profits and resist the economic recession.

\subsection{To optimize the investment structure and improve the market system}

In terms of the global financial market, futures business and futures investment funds have been fully developed in the United States. It also has the most perfect construction of regulatory system. In the United States, the construction of the regulatory system of the futures 
investment funds includes three aspects: the legal framework for regulating the futures investment fund, its regulatory system and its regulatory measures. China's futures business started late. Futures investment funds occupy an important position. During the regulatory process, successful experience of the United States should be actively learned and used. And the development of China's futures investment funds needs to be analyzed in detail in order to construct a reasonable regulatory mechanism. With the continuous improvement of the financial business, every investment group plays an important part. According to different types of futures funds, investors are also different. The rapid development of futures investment funds makes the role of institutional investors in the market more important. Therefore, institutional investors have to be further developed and the investment structure of the futures market should be constantly adjusted and improved in order to reduce the investors' risks and investment risks and to further optimize the investment structure to promote the development and progress of the futures market.

\section{Problems of china's futures investment funds}

With the continuous development of the futures market, although underground futures investment funds in China have developed for a long period of time, they still have some problems compared to the futures market in some developed countries. Specific problems can be shown from the following aspects:

\subsection{Lack of relevant legislation}

Although China's futures market develops rapidly and improves greatly in terms of the scale, the futures investment funds are lack of standardization and have certain defects in many aspects. To promote the standardization and development of futures investment funds should strengthen the construction of legal system. The improved legal system will guarantee the development of futures investment funds. At present, China still has a lot of problems in the legislation system of futures investment funds, and it has not promulgated the relevant regulations on futures investment funds. Due to the lack of effective laws and regulations, the development of futures investment funds has been severely restricted. In addition, the lack of relevant policies in the development of the China's futures investment fund has affected its development. While the underground futures investment funds in China develop relatively faster, the reason is lacking legislation, leading to the deviation from the direction of developing the futures investment fund.

\subsection{Lower professional level of managing financial affairs}

Currently, underground futures investment funds in China have few types. Underground futures investment managers mainly use a single type, and their main types of investment are speculation, arbitrage and hedging. Compared with some developed countries, these types of investment are too simple and lack of flexibility. Investment management personnel make use of investment tools, but their simple investment behavior, a lower design level and lack of effective usage of different investment tools result in the ineffective usage of investment tools. The investment behavior is difficult to fully play the role of investment tools. While the United States and other western countries use a variety of investment tools for futures investment. They combine various investment tools, and make a thorough analysis of the characteristics of the investment clients to design the most suitable investment products for the clients, which can improve the reasonability of investment products and also have a very positive impact on the development of futures investment funds.

\subsection{Client groups have limitations}

With the continuous development of China's futures investment funds, requirements for the investors become higher and higher. According to different futures investment funds, the choice of investors is also different, which makes the investment clients have limitations. At present, futures investment groups are limited to individuals, enterprises and listed corporations in China's futures market. Compared to some developed countries, there is a large gap between investors in China's futures market in terms of investment scope, operability and technologies. At the present stage, there are a lot of investors in the futures market in the United States-all types of investment institutions and individual investors can be involved in the investment of the futures investment funds, which can further promote the development of futures investment funds.

\subsection{Higher credit risks}

At present, there is a large number of private fund managers in China's futures investment market who have some investment experience. But compared to developed countries, China's financial market is not fully developed in many aspects for lacking perfect market and competitive mechanisms. And some private fund managers are lack of professional qualities and professional ethics, which makes private fund managers for the underground futures lack enough credibility and brings higher credit risks. 


\subsection{The unsatisfied construction of the internal and external regulatory mechanism}

Currently, underground futures investment funds still account for a large proportion in China's futures investment funds and the underground investment activity is not legitimate. Fund managers are lack of independence and relevant national departments don't make enough efforts for supervision, which results in a higher rate of internal transactions and other illegal operating acts. At present, with the development of China's futures investment funds, the risk brought by illegal operating acts has a great impact on the standardized development of the futures investment fund. Therefore, it's necessary to strengthen the construction of the legal system in order to ensure its development, which provides a powerful legal protection. Relevant national departments should actively guide the futures investment fund and give guidance to its right developmental directions. In order to achieve this goal, regulatory authorities must pay more attention to the development and supervision of futures investment funds.

\section{Measures to develop the futures investment fund}

\subsection{To constantly improve laws and regulations}

At present, China has to constantly improve laws and regulations of the futures investment fund in order to realize its fast and better development and provide a powerful institutional guarantee. It needs to strengthen the construction of the legal system in the market of the futures investment fund during the process of legislation and makes detailed analysis of the development of futures investment funds in our country based on which management regulations of the futures investment fund are formulated to guarantee its development and promote its legitimate and standardized development. In addition, it should take the development of the futures market into consideration and adjust the measures for managing futures investment funds. The restrictions to develop futures investment funds have to be canceled gradually, and the proportion of futures investment funds in the futures market should be expanded constantly in order to create a good environment for the market to promote the development of futures investment funds.

\subsection{To strengthen supervision and management}

There are a lot of futures investment funds in China's futures investment market which can also be called underground private funds. This kind of futures investment fund has no legitimacy. Investors face big investment risks and the investment income is not higher.
Therefore, private funds of the underground futures have to be brought into the legal system of the futures market to realize the standardized development of the private funds. Now China's private funds have been fully developed. According to the development of the underground futures fund, laws and regulations have to be strengthened to further improve its development and reasonable measures should be taken to guarantee its legitimacy and standardization. With the continuous development of China's futures market, the investors' demand for futures investment will grow bigger and bigger. Therefore, China has to strengthen supervision and management and the construction of the regulatory authorities to promote the development of China's financial business.

\subsection{To strengthen the construction of professional teams for investment}

In China's futures market, the development of the futures investment funds is very promising. Futures investment managers, as a major force to invest futures investment funds, their professional level and investment experience directly determine whether the futures investment funds can make profits and make a great value. Therefore, it is very important to strengthen the construction of professional teams for investment and improve the comprehensive ability of the managers for futures investment funds, so as to effectively make up for the shortage of talents in the futures investment fund market. With the continuous development of China's futures investment market, the demand for futures investment funds is growing bigger and bigger. However, lack of professional talents with high quality and high level has become an important issue in the development of China's futures investment market. Therefore, the construction of the talent team for futures investment funds should be strengthened in order to continuously improve the development. Specific measures are as follows: Firstly, to introduce foreign talents and learn from foreign successful experience. In the development of futures investment funds, outstanding fund management personnel have to be gathered together. The introduction of talents will alleviate the problem of talent shortage in China's futures market; secondly, to improve talent training mode and cultivate financial talents to meet the requirements of the China's financial market; thirdly, to take the method of vocational training and effectively improve investment fund managers' ability.

\section{Conclusion}

All in all, the development of the futures investment fund is of great significance for the development of China's financial market. In-depth study about it needs to be 
carried out to find problems and put forward effective measures so as to promote the development and progress of China's futures investment funds.

\section{References}

1. Xiao Duan, Jia Yuhe. 2004. "Ideas on developing China's futures investment funds," J. South China Finance, 6: 41-42, 40.

2. Liu Peng, Zhu Guohua. 2012. "Analysis on the necessity of developing the futures investment funds in China," J. Modern Management Science, 7: 28-30.

3. Wu Liping, Li Mei. 2009. "Strategic conceptions on the development of China's futures investment funds in the new period," J. Financial World, 1: 14-16. 